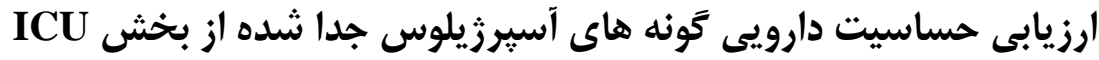 بيمارستان در شرايط آزمايشكاهى
}

$$
\text { آيت اله نصر الهى عمران }
$$

ا) كروه قارج شناسى، دانشكده يزشكى، دانشكاه آزاد (سلامى، والحد تنكابن، تنكابن، ايرلنغ 
تعميرات ناقص و عدم كارائى يا فقدان سيسـتم تهويـه

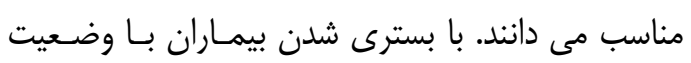

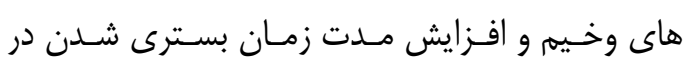

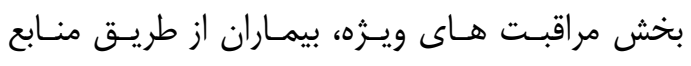

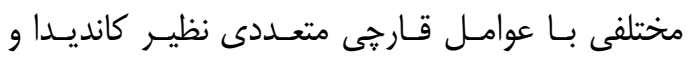

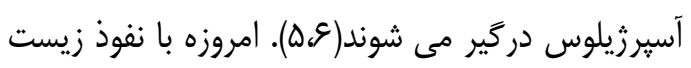

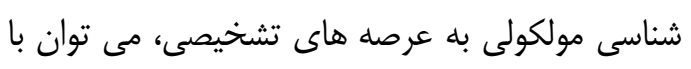

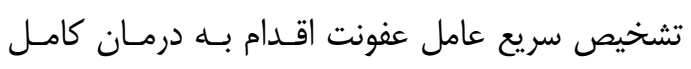

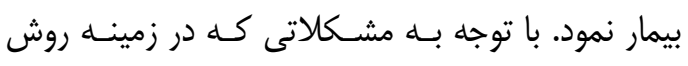

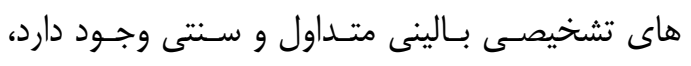

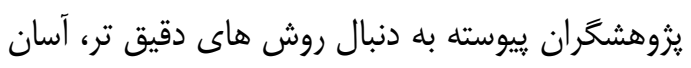

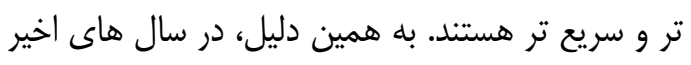

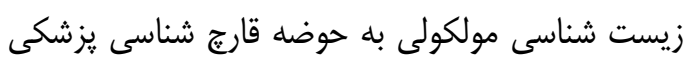

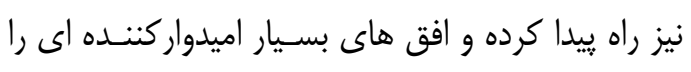

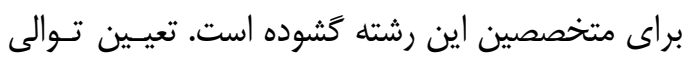

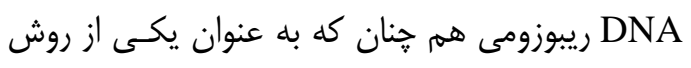

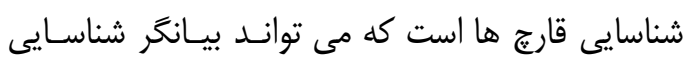

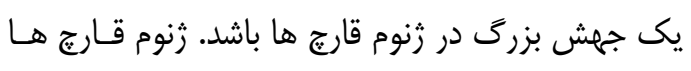

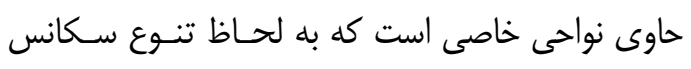

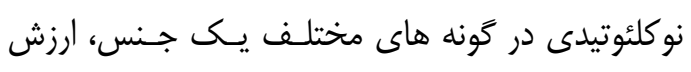

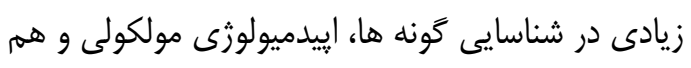

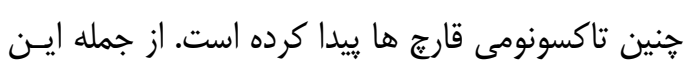

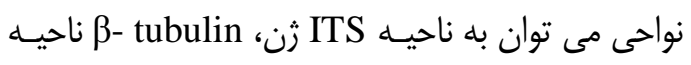

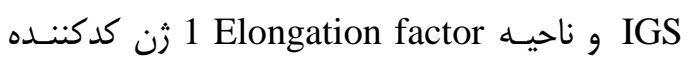
اشاره كرد. روش هاى مبتنى بر PCR مى توانند روش

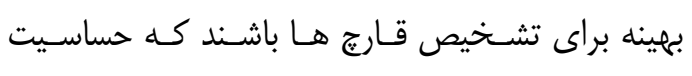
بيشترى نسبت به ساير روش ها دارند و در مـواردى در

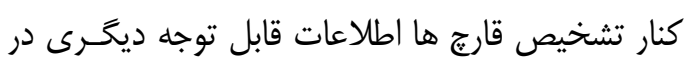

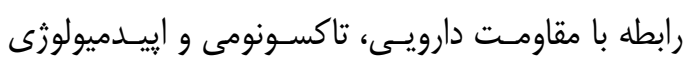

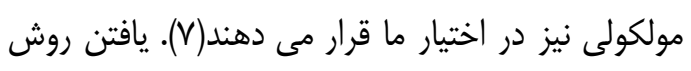

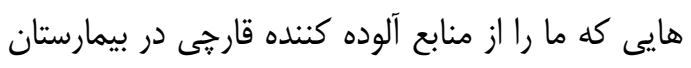

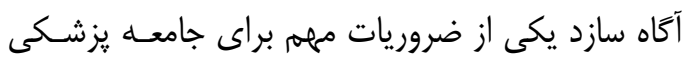
مى باشد. على رغم ييشرفت هاى ضد قارجى و كيفيت

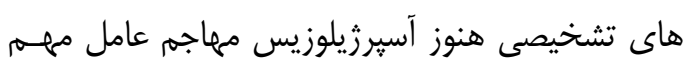

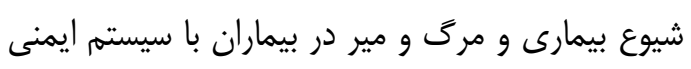

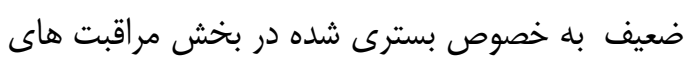

\section{مقدمه}

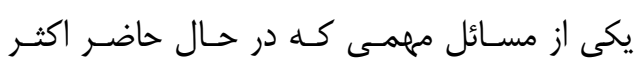

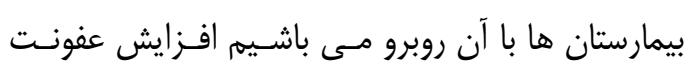

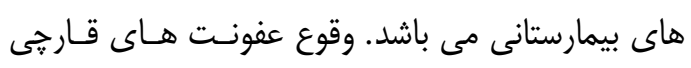

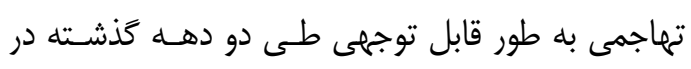

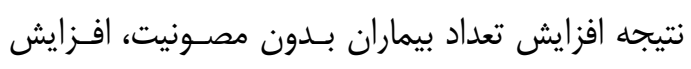

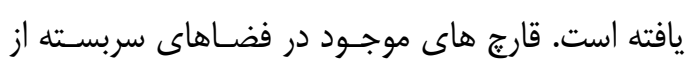

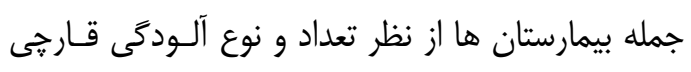

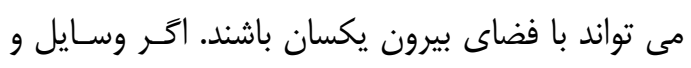

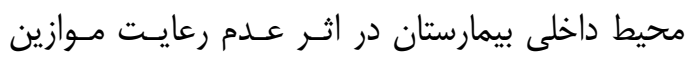

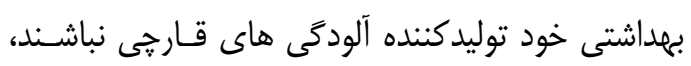

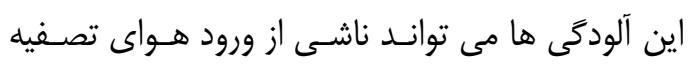

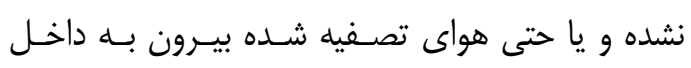

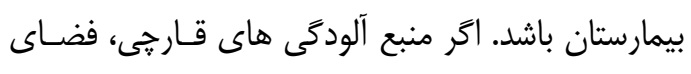

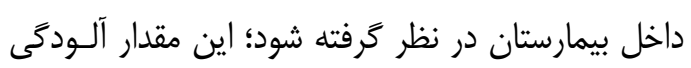

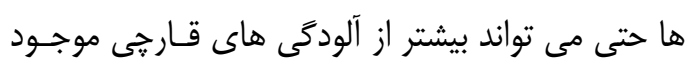

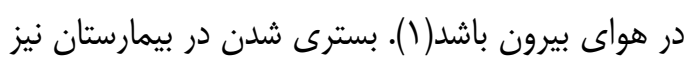
اثر مهمى روى كلونى سازى قارج ها در بيمـاران اخيـر در بيمارستان ها داشته است؛ بنا بـر ايـن ايــن بيمـاران

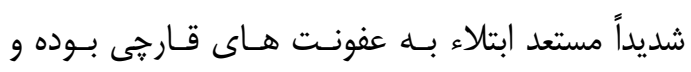

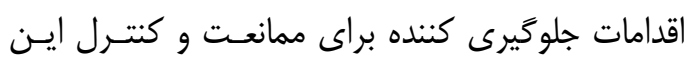

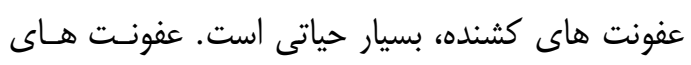

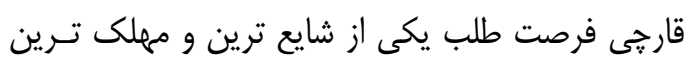

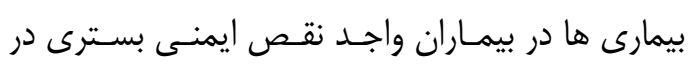

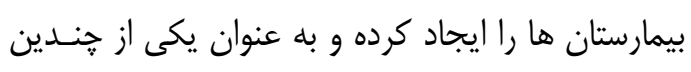

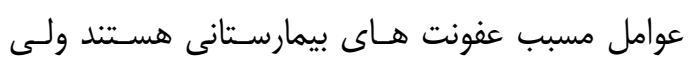

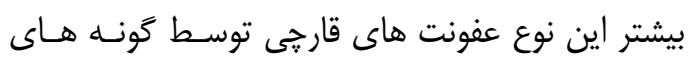

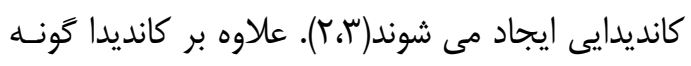

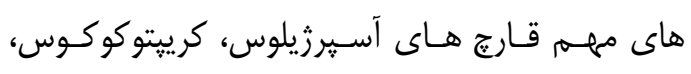
زايكومايست ها، فوزاريوم، سدوسبوريوم و ينى سليوم بـ هـئ

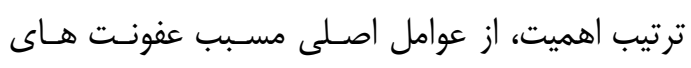

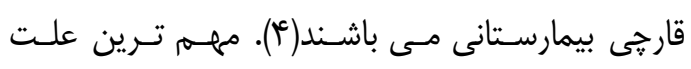

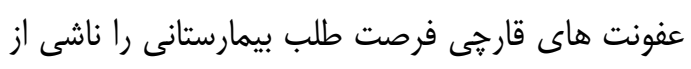

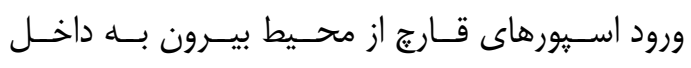
بيمارستان مى دانند كه در مواردى حتى اين عفونت ها إنـا

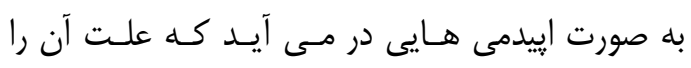


قارجى يك موضوع مهم قابل يِيخيرى در قارج شناسى

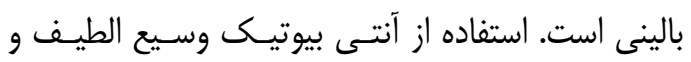

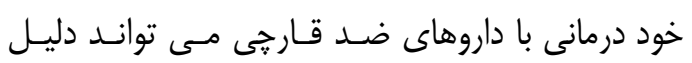

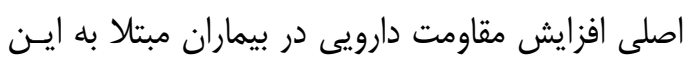

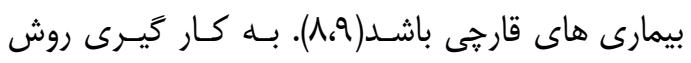

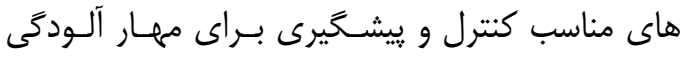

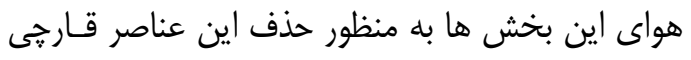

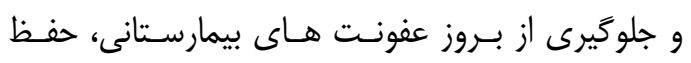

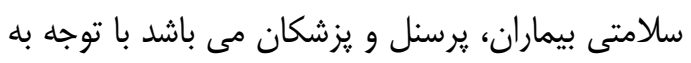

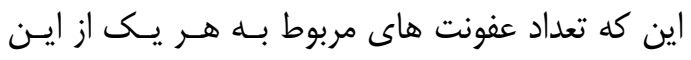

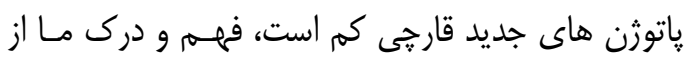

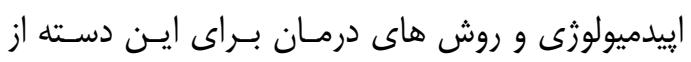

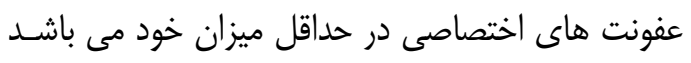

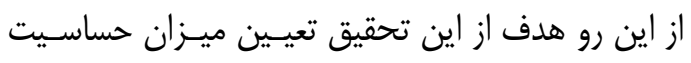

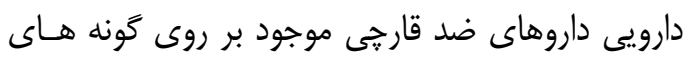

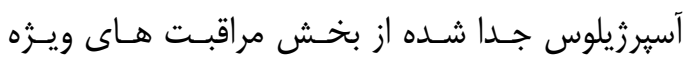

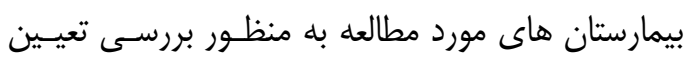

حساسيت قارج هاى جدا شده بود.

\section{مواد و روش هاس هات هاى جان}

اين مطالعه بله صورت تحليلى -مقطعى به مـدات 9

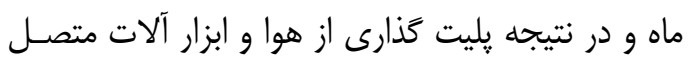

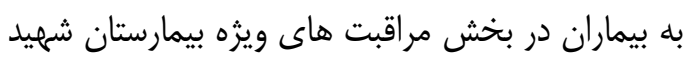

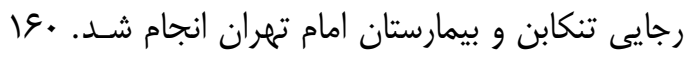

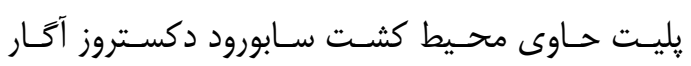
شركت(آلمان Merk حاوى كلرامفنيكل و بــــ (SDA)

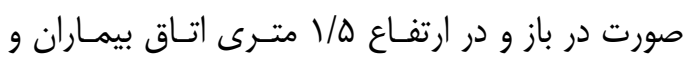

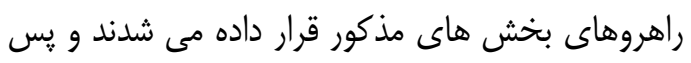

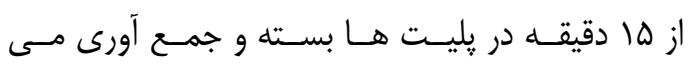

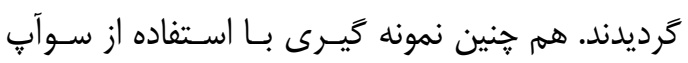

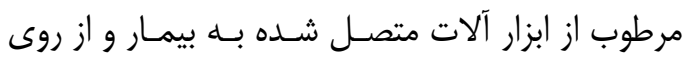

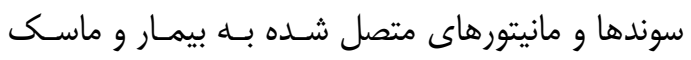

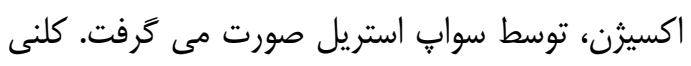

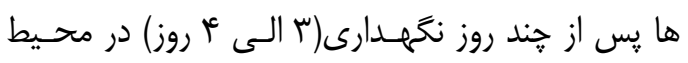

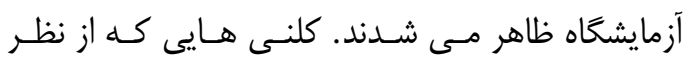
ميكروسكويى و ماكروسكويى مشكوك به آسـبرزيلوس

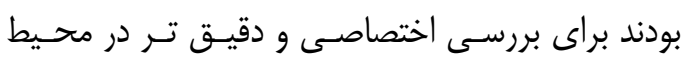

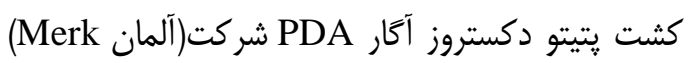

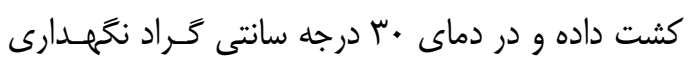

ويزه محسوب مى شود. احتمال ابتلاء به اين ميكـروب

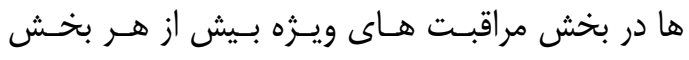

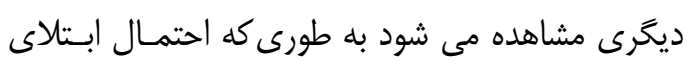

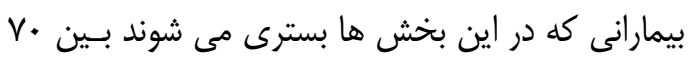

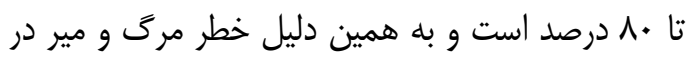

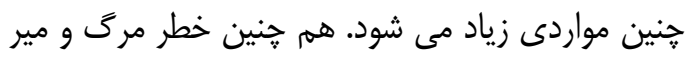
ناشى از عفونت هاى بيمارستانى در بيشتر كشورها بين

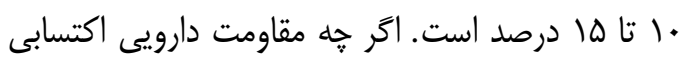

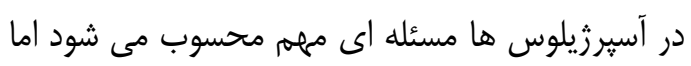
كونه هاى آسيرزيلوس فوميكاتوس ممكـن اسـت ذاتـاً

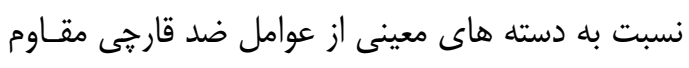

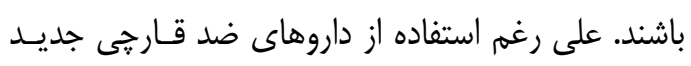

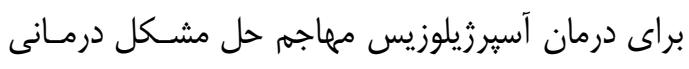

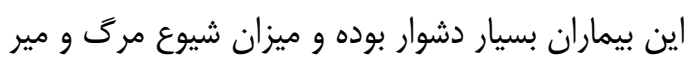

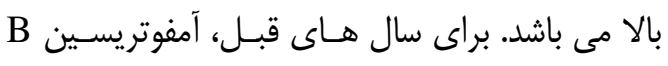

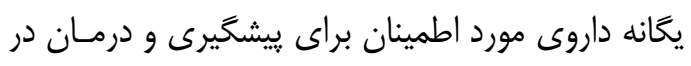

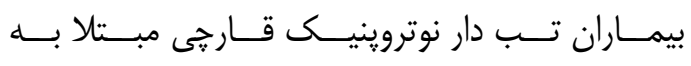

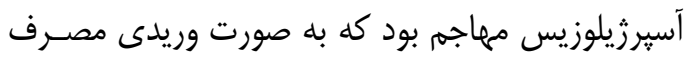
مى شده است تا اين كه داروهاى ترى آزول هاى جداى جديد

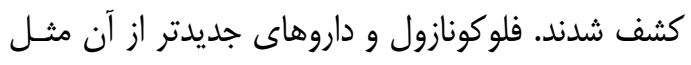

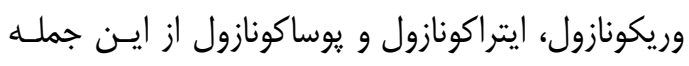

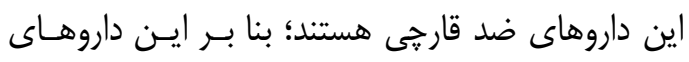

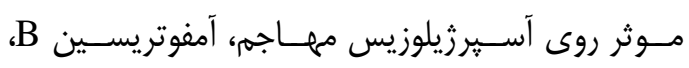

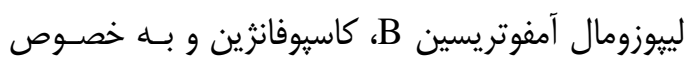
وريكونازول مى باشند(م). مقاومت آسـيرزيلوس هـا يـا در

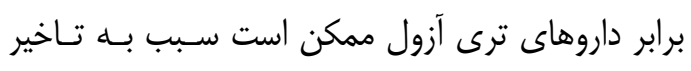

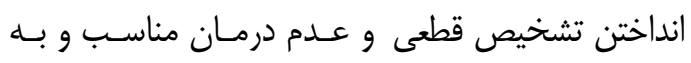

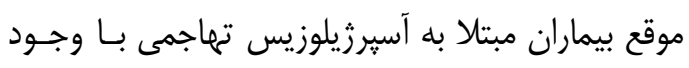

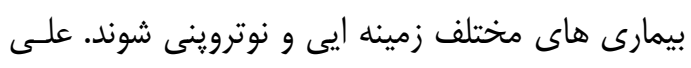

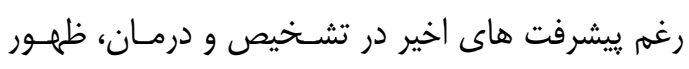

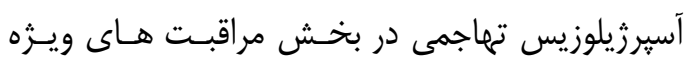

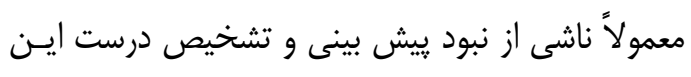

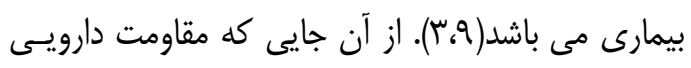

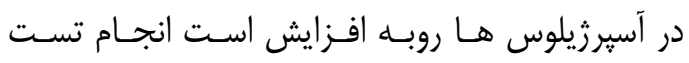

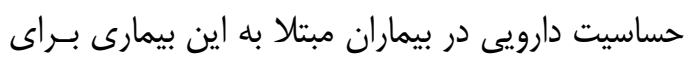

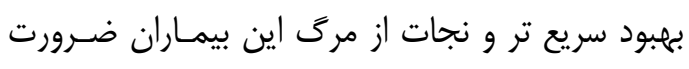

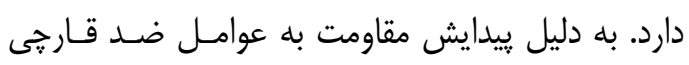

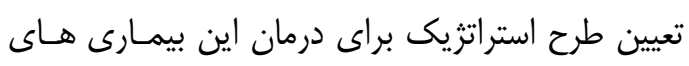


جهت تكثير ناحيه ITS شامل واسرشتخى اوليه

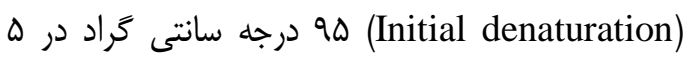

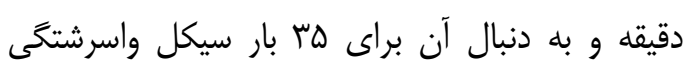

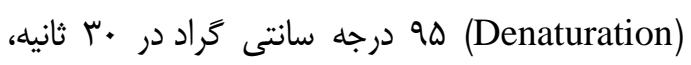

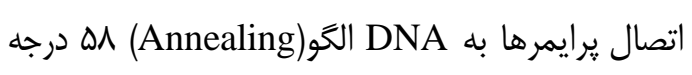
سانتى كراد براى • ب ثانيه، دماى طويل شدن رشته الخو

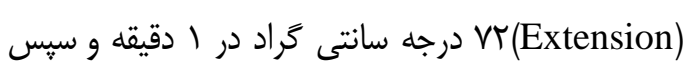

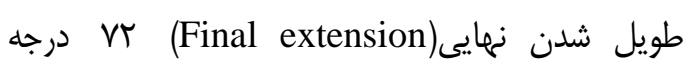
سانتى گراد در ه دقيقه انجام شد. با توجه به اندازه

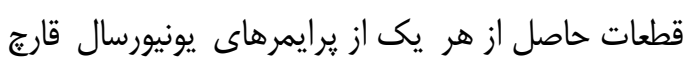

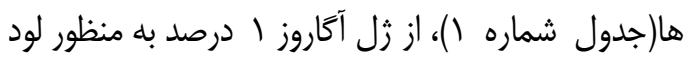

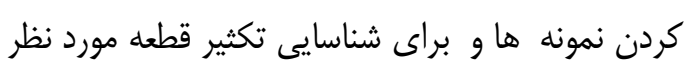

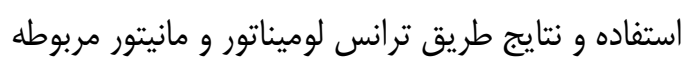

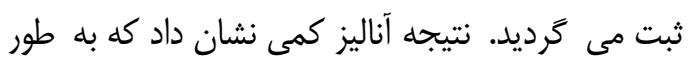

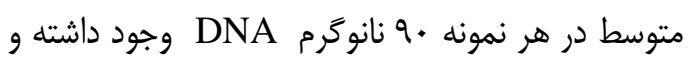

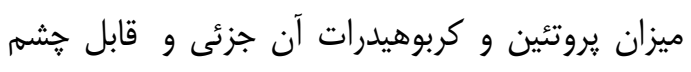
يوشى است. بر اساس غلظت حاصله مقدار ه ميكروليتر Dن زنومى براى PCR به عنوان الخو مناسب بود.

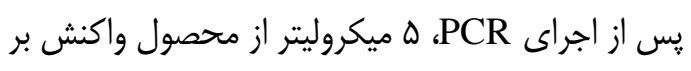
روى زل آكاروز model

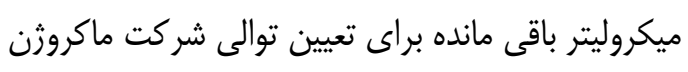

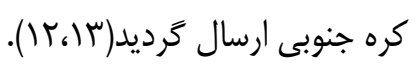

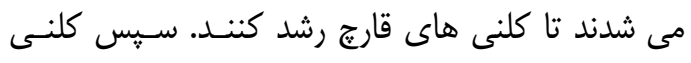

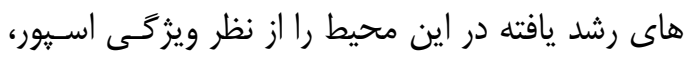

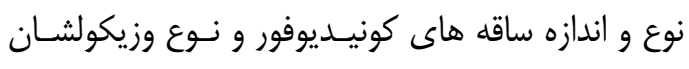

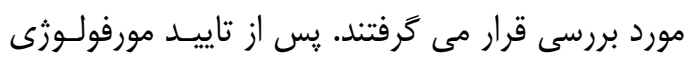

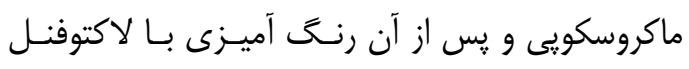

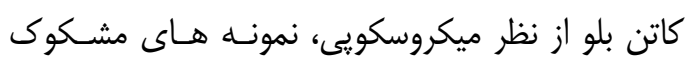

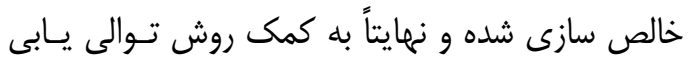
مورد بررسى و شناسايى قرار مى كرفتنداء •(1).

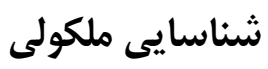

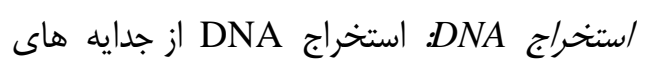
قارجى آسيرزيلوس به وسيله كيت تجارى Geno PlusTM Genomic DNA Extraction ساخت شركت ت شايوانى طiogene كرفت(1). واكنش PCR براى ناحيه ITS (نواحى (1)

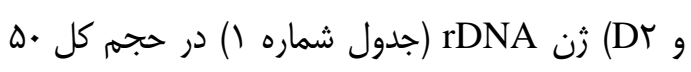
ماكروليتر با تركيبات زير اجراء شد. براى انجام شاره واكنش

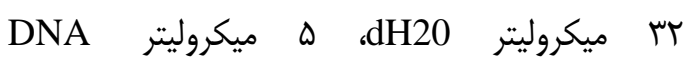
\& polymerase Buffer(10x) dNTP Mix(10 ميكروليتر (MgCL2(25Mm)

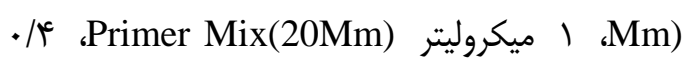

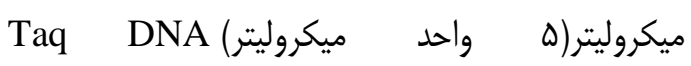

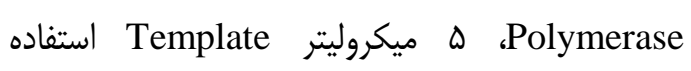

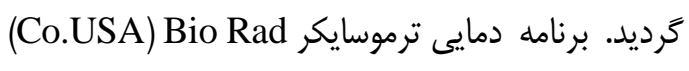

جدول شماره ا. ناحيد برايمرهاى يونيور سال قارج ها

\begin{tabular}{ccc}
\hline يرايم & توائ & (5'- TCCGTAGGTGAACCTGCGG-3') \\
\hline Forward primer(ITS1) & 500-600 \\
Reverse primer(ITS4) & (5' - TCCTCCGCTTATTGATATGC-3') & \\
\hline
\end{tabular}

يافته و مطابق با روش Broth Microdilution تست

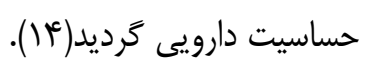

تهيه سوسيانسيون قارجيى: در ابتدا از كشت هاى

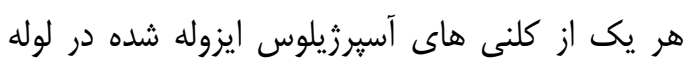

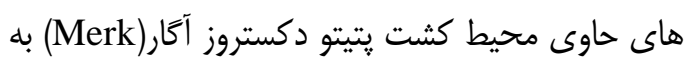
كمك اضافه كردن يك ميلى ليتر آب مقطر استريل و يك قطره توين ·r، سوسيانسيون اوليه اسبور تهييه و
تست حساسيت دارويى /يزوله هاى مورد مطالعه نسبت به داروهاى ضد قارجى مطابق با روش استاندارد

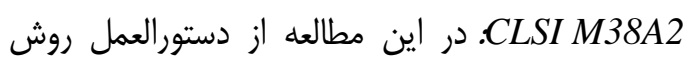

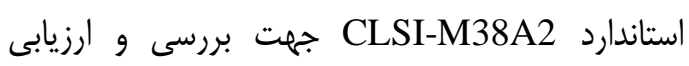

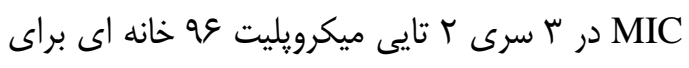
آسبرزيلوس هاى شناسايى شده از كلنى هاى ريك رشد 
جاهك دو تا مانده به آخر حاوى كمترين غلظت دارو بود. در خاهك هاى اول تا دو تا مانده بـ آخر مقدار

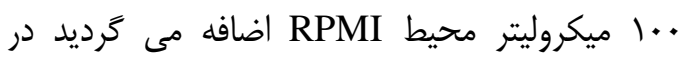
ادامه ..1 ميكروليتر از سوسيانسيون تلقيحى فينال به ميه

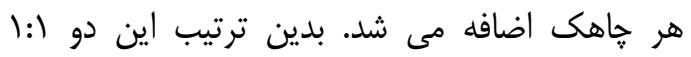

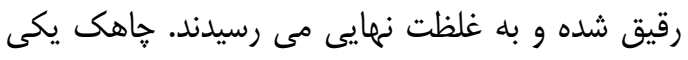

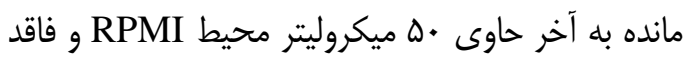

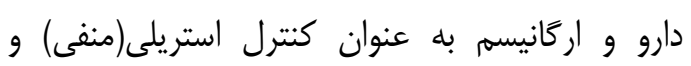

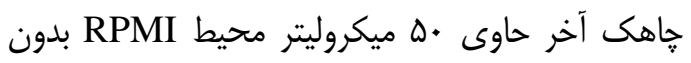

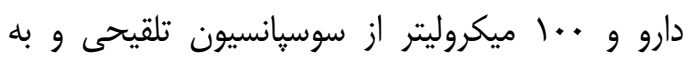
عنوان كنترل رشد(مثبت) جهت مقايسه رشد با ساير جاهى ها در نظر گرفته مى شد. در ادامه ميكرويليت

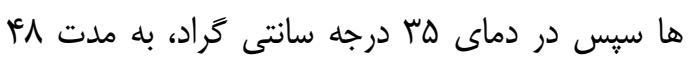

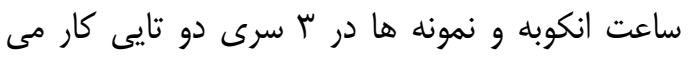

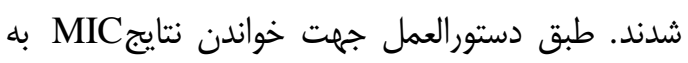

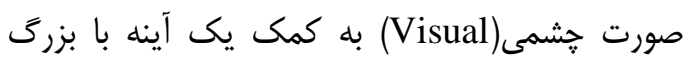

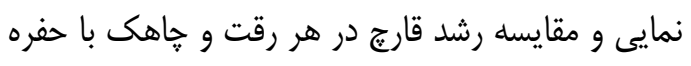

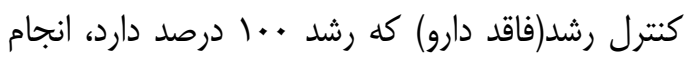

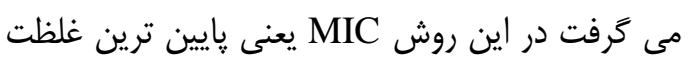

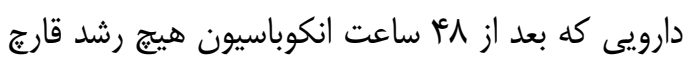

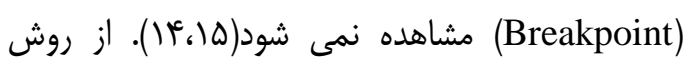

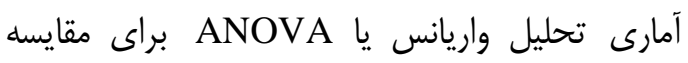
ميانكين داده هاى MIC هر دارو با استفاده از نرم افزار SPSS

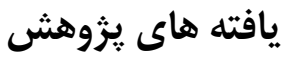

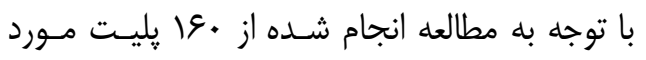

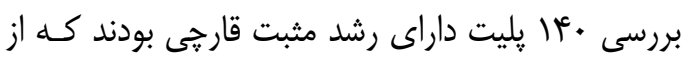

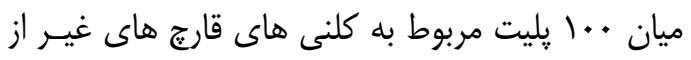

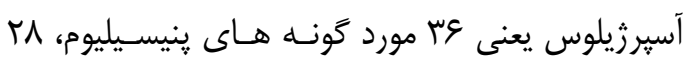

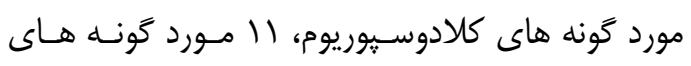

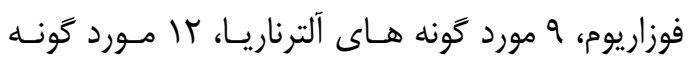

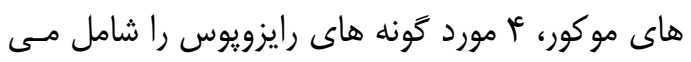

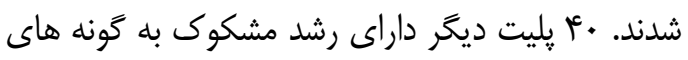

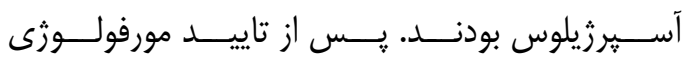
ماكروسكويى و سيس مورفولوزى ميكروسكويى نمونسه

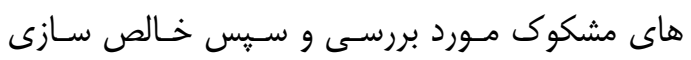

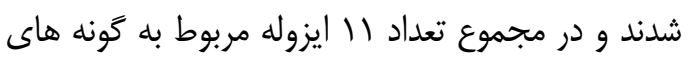

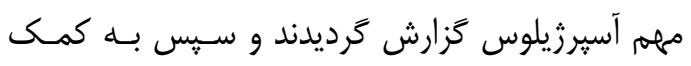

سبس به لوله استريل ديخرى منتقل مى كرديم و سيس به كمك ورتكس به مدت مات أنانيه سوسيانسيون تهيه شده را خوب مخلوط كرده و در ادامه اسبورهاى

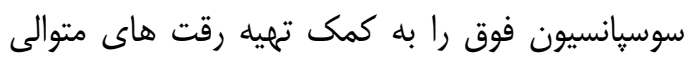

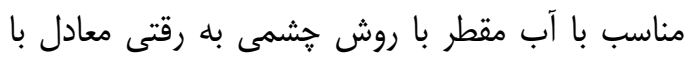

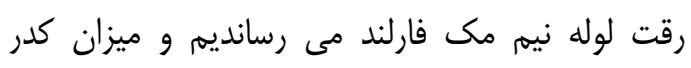

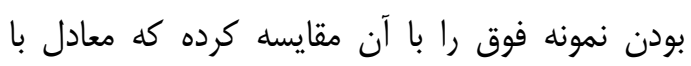

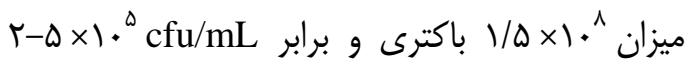

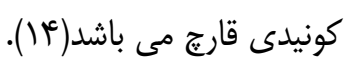

تهييه محلول مادر و تهييه رقت هاى داريد دارويى مختلف از داروهاى مورد مطالعه: طبق راهنماى CLSI داروها ماريه

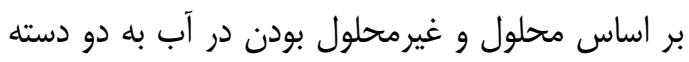

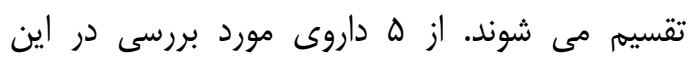

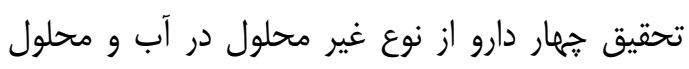

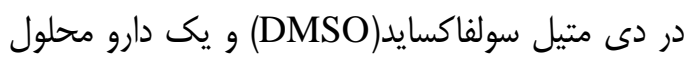

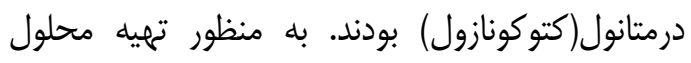

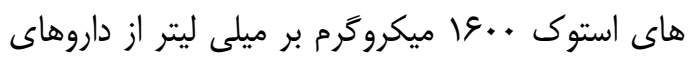

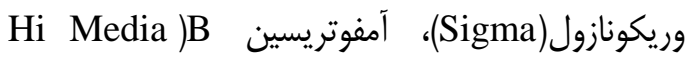
Sigma India

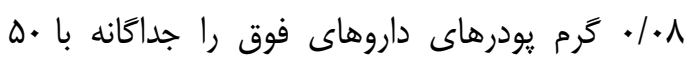

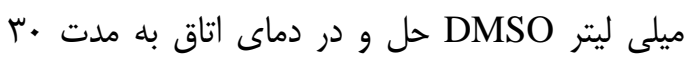

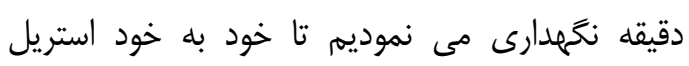

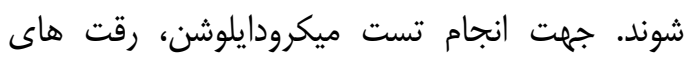
هrاس./ تا عا ميكروگرم بر ميلى ليتر از ايتراكونازول

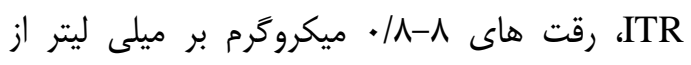

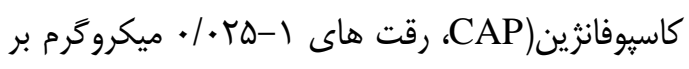

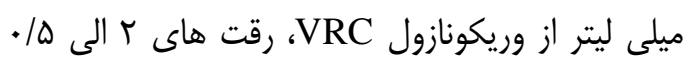

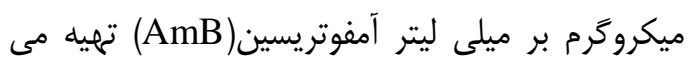

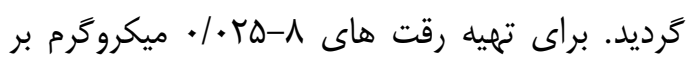

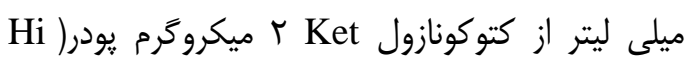
Media India

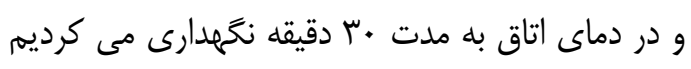
تا خود به خود استريل شود(ه(، أ()). انجام تست Broth Microdillution يروتكل، رقت هاى سريال براى هر داروى مورد بررسى

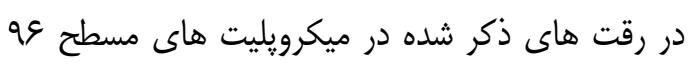

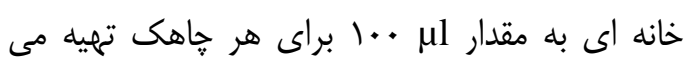
شد به طورى كه جاهى اول حاوى بيشترين غلظت و 


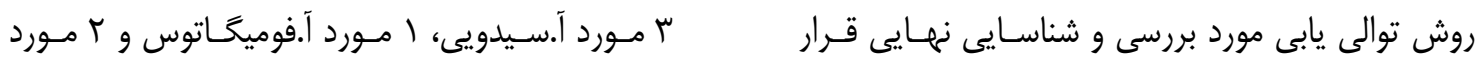

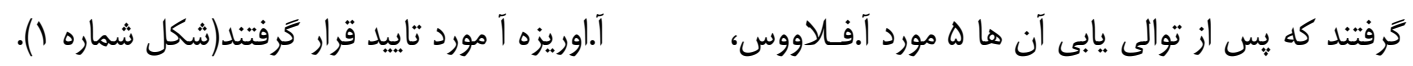

M123456

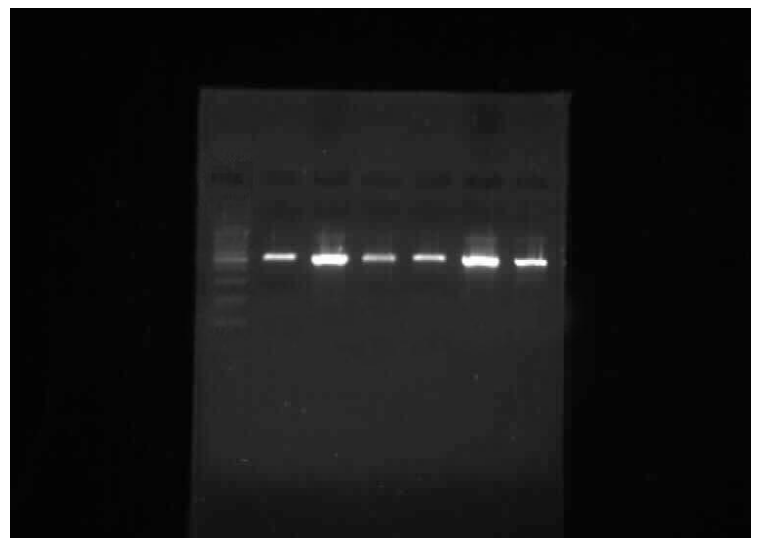

شكل شماره ا. نماى الكتروفورز از تكثير زن ITS محصول تكثير PCR. باندهاى تشكيل شده تقريباً يكسان حاصل از

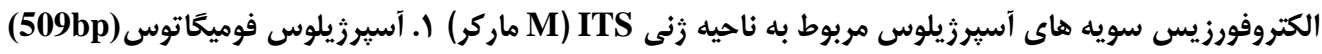

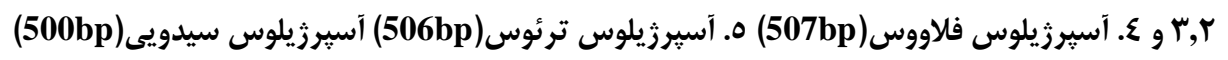

ميكروگرم بر ميلى ليتر بودند(هأ(I). آ.سيدويى مقاوم

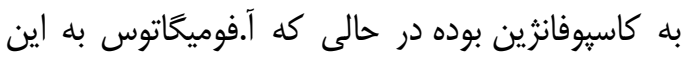

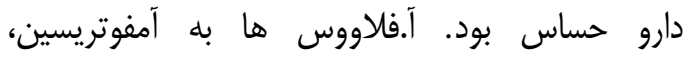

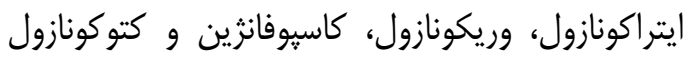

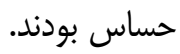

نتايج تست حساسيت دارويى: با توجه به بررسى نتايج ميانخين دامنه MIC براى ايزوله هاى لتاى

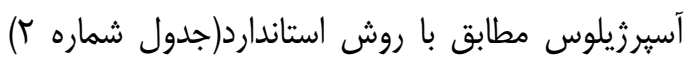

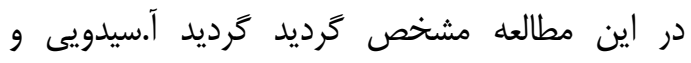

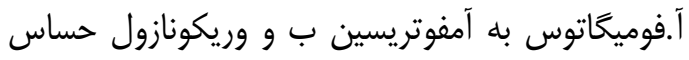

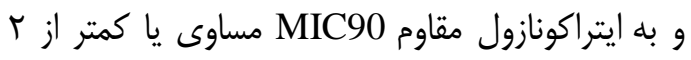

جدول شماره r. نتايج تست حساسيت دارويى آسيرزيلوس هاى جدا شده نسبت به داروهاى

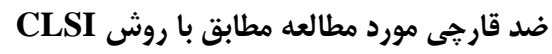

\begin{tabular}{|c|c|c|c|c|c|c|c|c|c|}
\hline \multicolumn{3}{|c|}{ آسيرزيلوس فلاووس } & \multicolumn{3}{|c|}{ أسيرزيلوس فوميكاتوس } & \multicolumn{3}{|c|}{ آسيرزيلوس سيدويى } & \multirow[t]{2}{*}{ 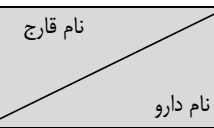 } \\
\hline $\begin{array}{l}\mathrm{MIC}_{\mathrm{q}} \\
\mu \mathrm{g} / \mathrm{ml}\end{array}$ & $\begin{array}{l}\text { MIC } \Delta . \\
\mu \mathrm{g} / \mathrm{ml}\end{array}$ & $\begin{array}{c}\text { دامله } \\
\mu \mathrm{g} / \mathrm{ml}\end{array}$ & $\begin{array}{l}\text { MIC }_{4} \\
\mu \mathrm{g} / \mathrm{ml}\end{array}$ & $\begin{array}{l}\text { MIC } \Delta . \\
\mu \mathrm{g} / \mathrm{ml}\end{array}$ & $\begin{array}{c}\text { دامو } \\
\mu \mathrm{g} / \mathrm{ml}\end{array}$ & $\begin{array}{l}\mathrm{MIC}_{\mathrm{q}} \\
\mu \mathrm{g} / \mathrm{ml}\end{array}$ & $\begin{array}{l}\text { MIC } \Delta . \\
\mu \mathrm{g} / \mathrm{ml}\end{array}$ & $\begin{array}{c}\text { دامن } \\
\mu \mathrm{g} / \mathrm{ml}\end{array}$ & \\
\hline$\cdot / \Gamma \Delta$ & $\cdot / / T \Delta$ & $\cdot / R T \Delta-r$ & $r$ & 1 & & $r$ & 1 & - & ايتراكونازول (ITZ) \\
\hline.$/ 1 T \Delta$ &.$/ T \Delta$ & $\cdot / \cdot \Gamma \Delta-s / S$ & $\cdot / \Delta$ &.$/ T \Delta$ & $\cdot / \cdot r \Delta-\Lambda$ & 1 & $\cdot / \Delta$ & $. / \cdot T \Delta-I T / A$ & كتوكونازول(KTZ) \\
\hline.$/ T \Delta$ &.$/ 1 T \Delta$ & $.1 .9-1$ & . /Tra & . & (1) &.$/ \Delta$ &.$/ T \Delta$ & $. / . \mu I r \Delta-1$ & وريكونازول(VRC) \\
\hline.$/ 1 T \Delta$ & ع gr./. & $\cdot / \cdot \mu \mid-\cdot / \Delta$ & .1 .94 & r & $\cdot / \cdot \lambda-\Lambda$ & .1 .9 & 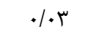 & $\cdot / \cdot \Lambda-\Lambda$ & كاسيوفانثين(CAP) \\
\hline$\cdot / \Delta$ & $\cdot / \pi \Delta$ & $\cdot / D-F$ & 1 & $\cdot / \Delta$ & $\cdot / \Delta-r^{c}$ &.$/ \Delta$ & . T⿱宀八 & $\cdot / \Delta-r^{c}$ & آمفوتريسين ب(AMB) \\
\hline
\end{tabular}

يى مظنون شدن به بيمارى شروع شده و تا زمان

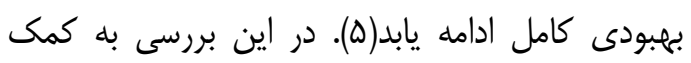

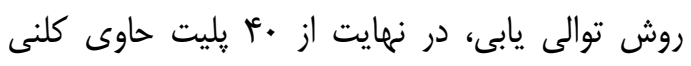

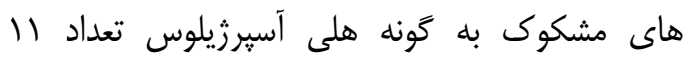

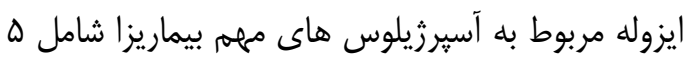

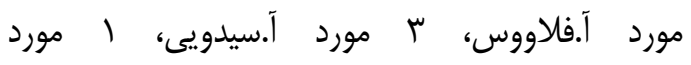

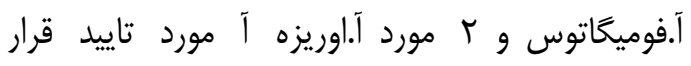

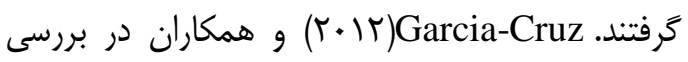

\section{بحث و نتيجه كيرى}

مديريت درمانى موفقيت آميز آسيرزيلوزيس مهاجم دئه وابسته به شروع به موقع درمان، انتخاب داروى موثر مورين

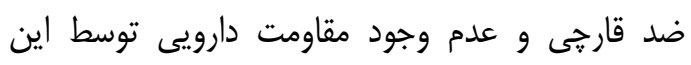
قارج مى باشد. تشخيص آسبرزيلوزيس تهاجمى بسيار

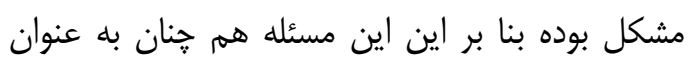
يكى از مشكلات اساسى در قارج شناسى بالينى مطرح

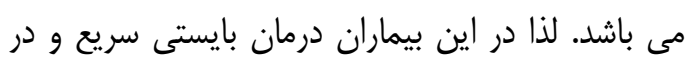


دو به ايتراكونازول مقاوم بودند. در ضمن آسبرزيلوس

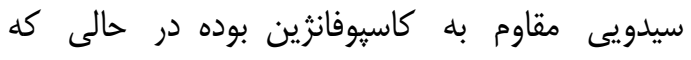

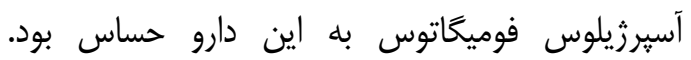

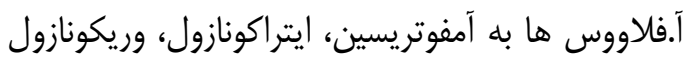

$$
\text { و كاسيوفانزين و كتوكونازول حساس بودند. }
$$

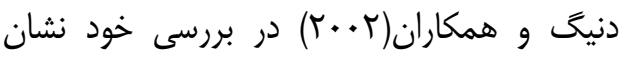

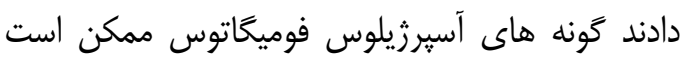
به طور ذاتى نسبت به داروهاى ضد قارج ها مقاوم

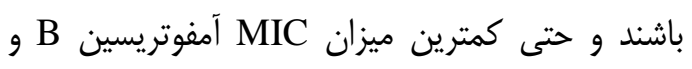

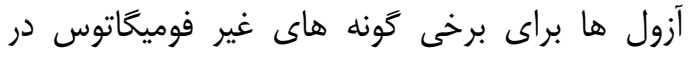

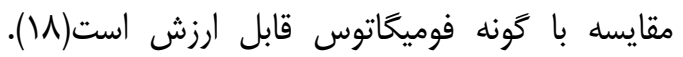

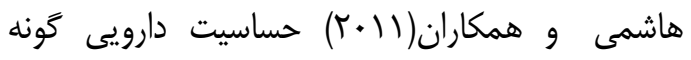

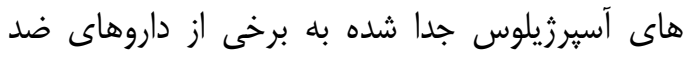

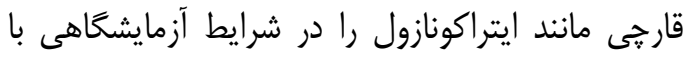

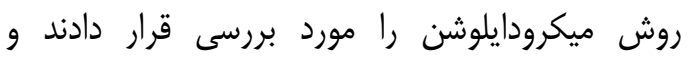

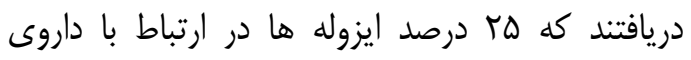

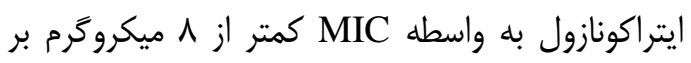
ميلى ليتر، ايزوله هايى با حساسيت كمتر تلقى مي إنى

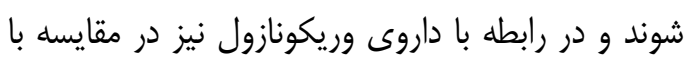

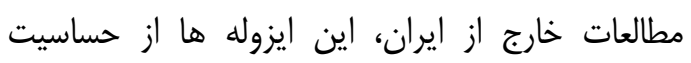

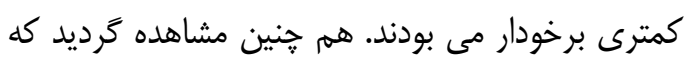
MIC اين ايزوله ها در اكثر موارد در دامنه

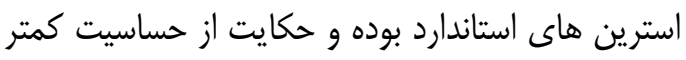

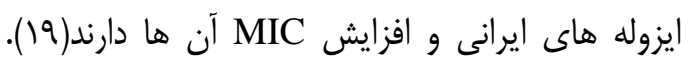

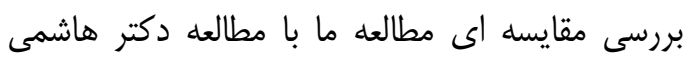

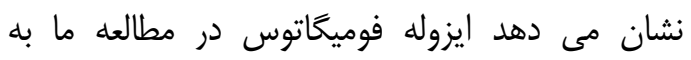

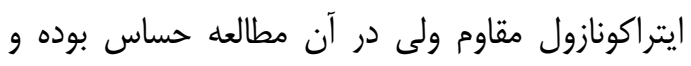

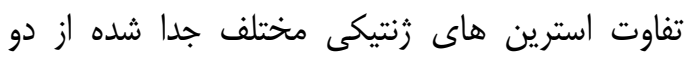

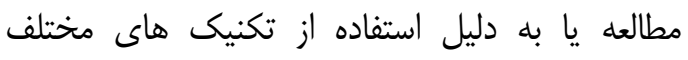

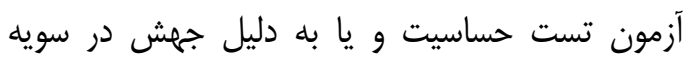

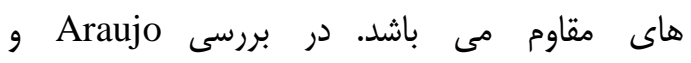

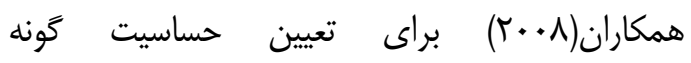

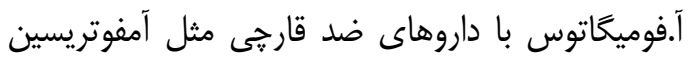

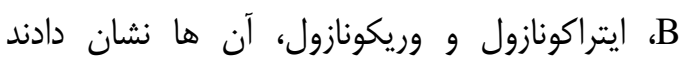
محدوده MIC براى اين سه دارو برابر و.٪

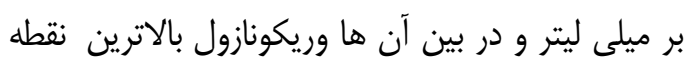
MIC داشت( •r). در بررسى نتايج تست حساسيت دارويى توسط دون
آلودَى قارجى و باكتريايى سطوح داخلى بيمارستانى در

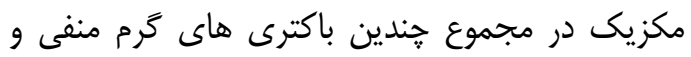

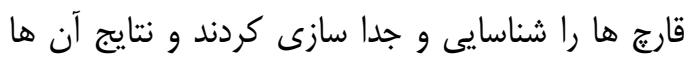
نشان داد كه غالب باكترى هاى شناسائى شائ شده شامل كونه هاى كلبسيلا، سودوموناس و اشريشياكلى و هم

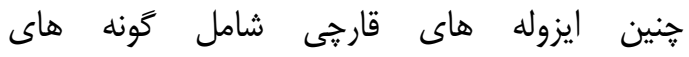

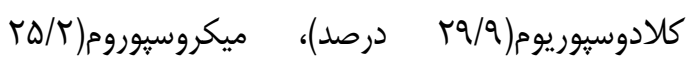

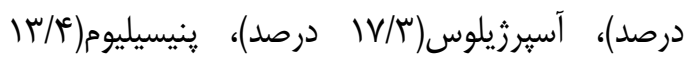

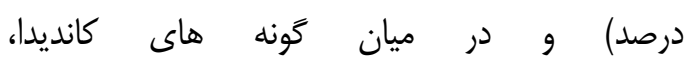

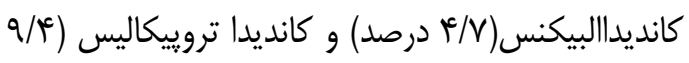

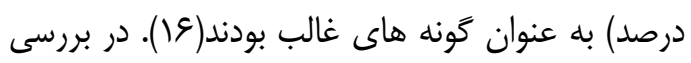

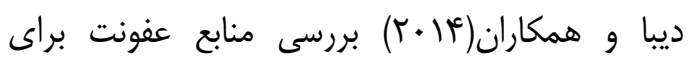

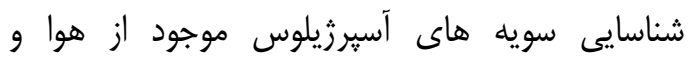

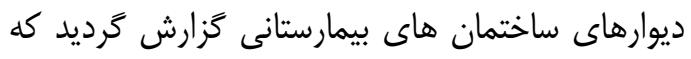

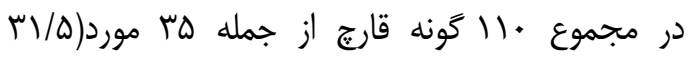

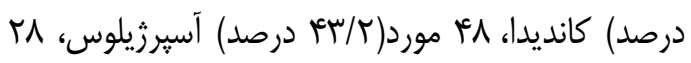

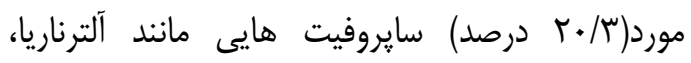

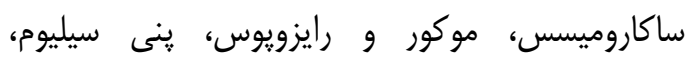
كلاوسيوريوم از طريق روش ملكولى شناسايى شدند و إندو غالب آسيرزيلوس جدا شده در اين مطالعه شامل آ.نيجر T/V

$$
\text { (I)/V }
$$

با توجه به نتايج بررسى دو مطالعه فوق و مقايسه

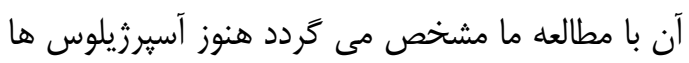

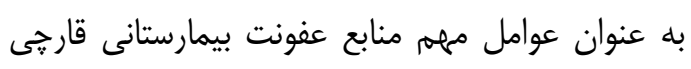

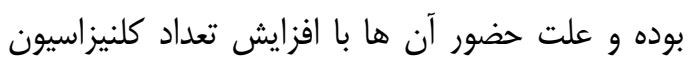

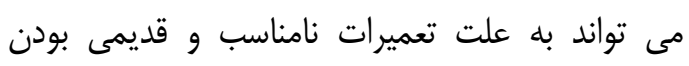
ساختمان ها، عدم كارائى يا فقدان سيستم تهان تهويه

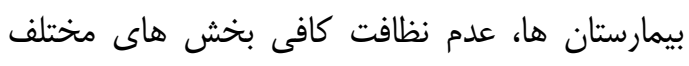

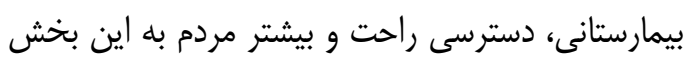

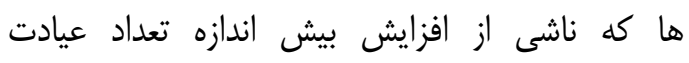

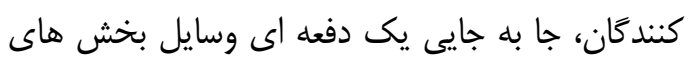

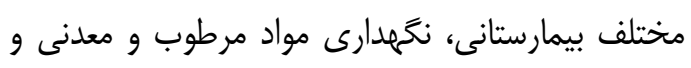
وجودكابينت مرطوب در ارتباط باشند.

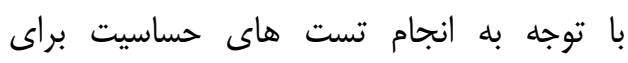
آسبرزيلوس هاى ايزوله شده در اين مطالعه مشخص آنس

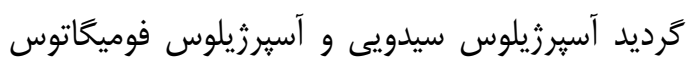
به آمفوتريسين و وريكونازول حساس در حالى كه هر 
داراى حساسيت كمتر از ا ميكروگرم بر ميلى ليتر را

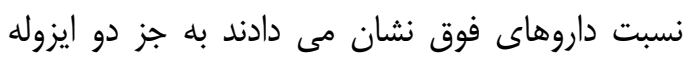

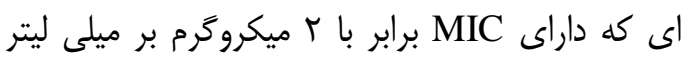

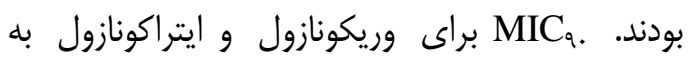

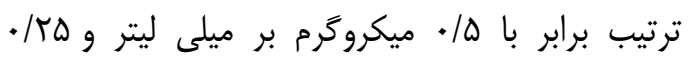

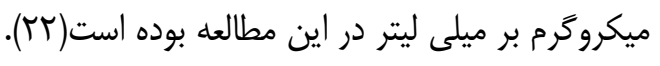

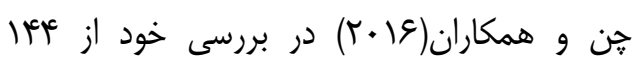
نمونه محيطى آسيرزيلوس فوميكاتوس جمع آورى شده

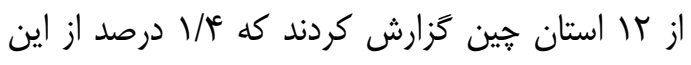

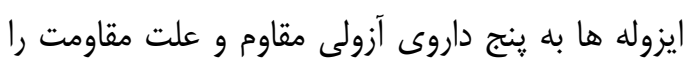

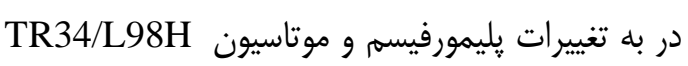

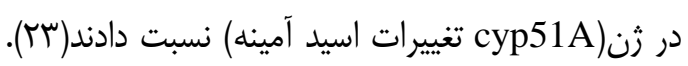

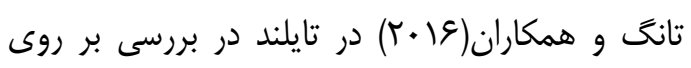

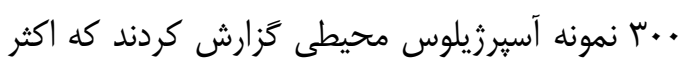

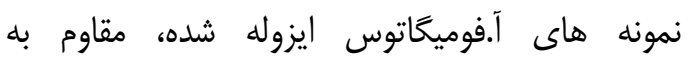

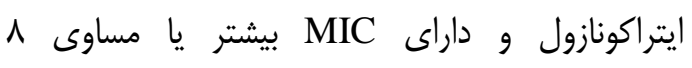
ميكروگرم بر ميلى ليتر بودند در حالى كه فقط دو ايزوله بئه

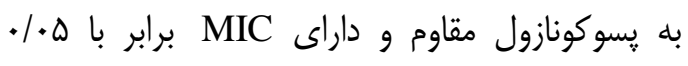

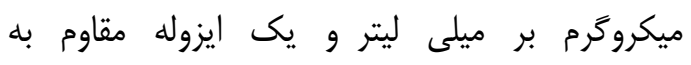

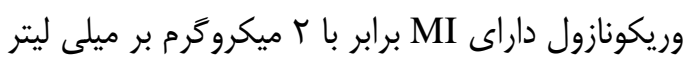
بودند(آب). نتيجه اين بررسى نيز با مطالعه ما در مبحث

$$
\text { مقاومت دارويى شباهت دارد. }
$$

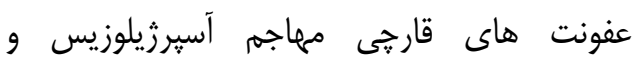

كانديديوزيس در حال ايجاد مشكل حاد براى بيماريت إنارن

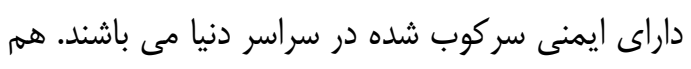

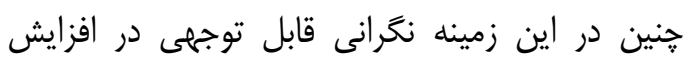
تدريجى مقاومت در برابر آزول هاى و واكين اكينوكاندين

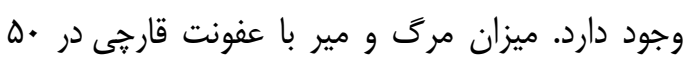

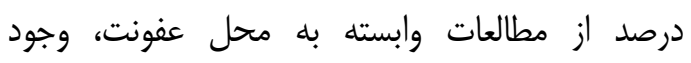
بيمارهاى زمينه اى مى باشد از اين رو استفاده از

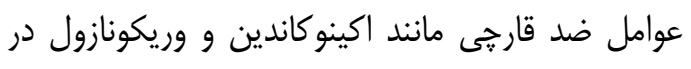
درمان هنين بيمارى هايى در حال حاضر در ارجحيت

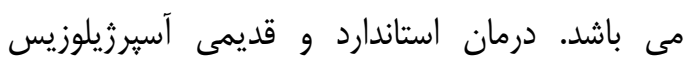

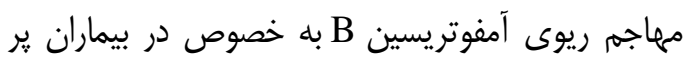

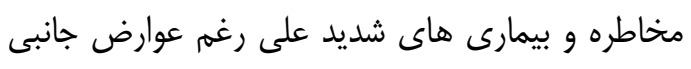
متعدد، به ويزه عوارض كليوى با حداكثر دوز قابل تحمل استفاده مى شود اين در حالى است كه ياسخ

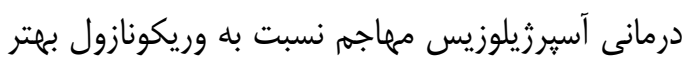

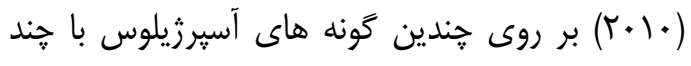

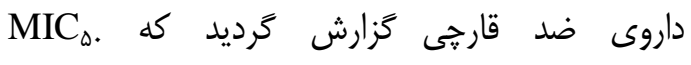
كاسيوفونجين براى آ.فوميكاتوس، آ.فلاووس و و آ.نيجر

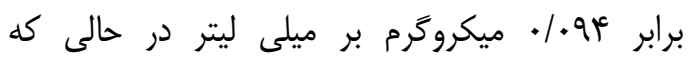

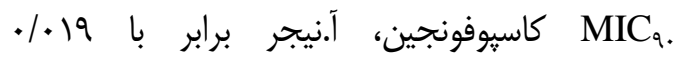

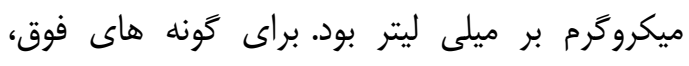

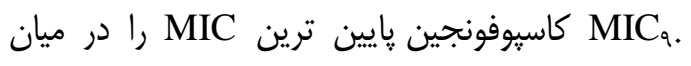
پينج داروى ضد قارجى را دارا بود. براى آ.ترئوس،

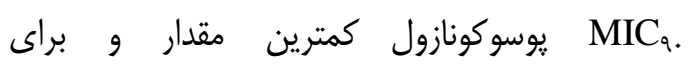

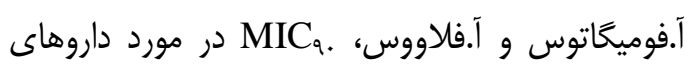

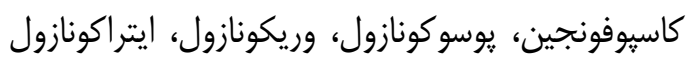

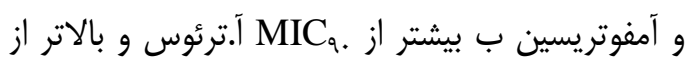

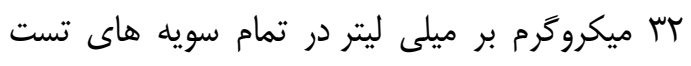

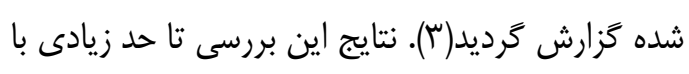

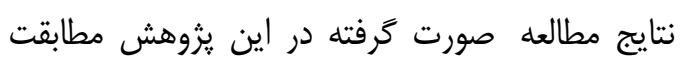
داشته است. بررسى نتايج تست حساسيت در اين نوع مطالعات و مقايسه آن با مطالعه ما نشان مى نى دهد

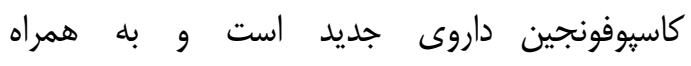
وريكونازول به عنوان داروى انتخابى مورد تاييد اكثر داست دانشمندان در درمان آسيرزيلوزيس مطرح مى بان داشد.

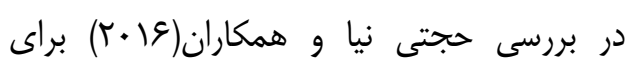
تعيين تست حساسيت ·r نمونه آ.فلاووس محيطى نمارن

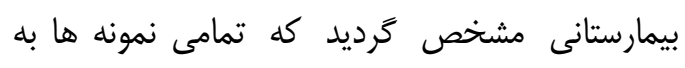

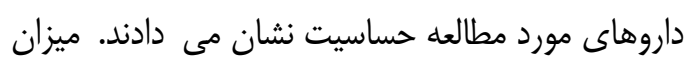

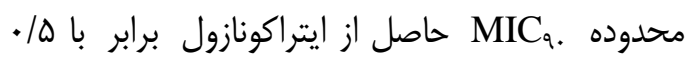

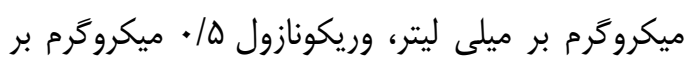

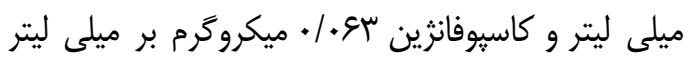

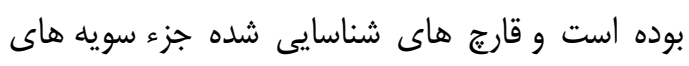

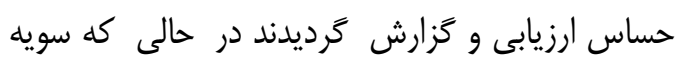

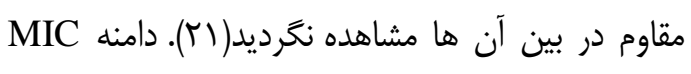

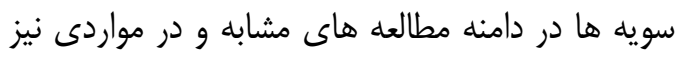

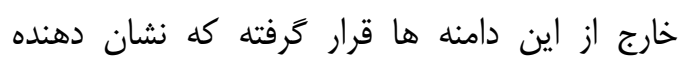
حساسيت بيشتر سويه هاى مورد مطالعه بود.

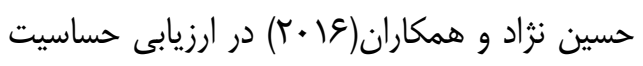

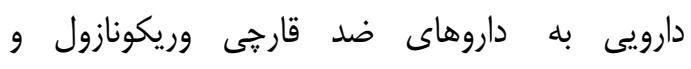

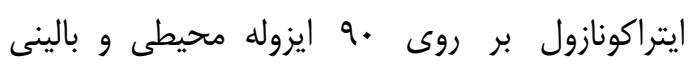

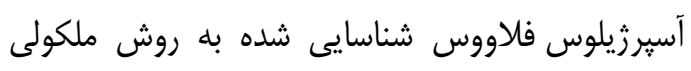

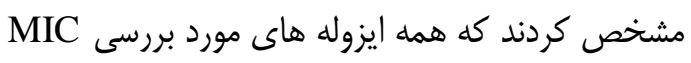


تفاوت در جامعه مورد مطالعه باشد. به دليل تفاوت در ياسخخَويى به داروها و امكان بروز مقاومت و انتقال مقاومت، بررسى مداوم تاثير داروهاى ضد قارجى از طريق روش هاى تعيين حساسيت نسبت به گونه هاى بيماريزاى آسيرزيلوس امرى ضرورى است لعين حسن كه بايد مورد توجه هم يزشكان و هم ميكروبيولوزيست ها قرار كيرد. علاوه بر ييشرفت هايى كه در ساليان اخير در

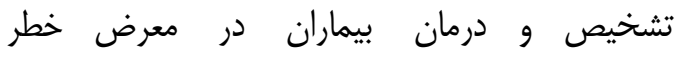

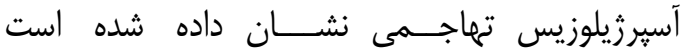
برنامه ريزى هاى لازم نيز بايستى در جهت اقدامات

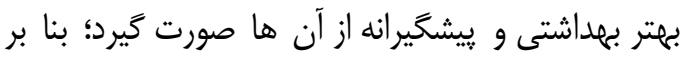
اين بيشنهاد مى گردد براى دسترسى به موفقيت درمانى بهتر در ارتباط با اين بيمارى مطالعات بيشترى و با داروهاى تركيبى همراه با بررسى اثرات سينرزيسمى اين داروها با داروهاى نوظهور انجام گيرد.

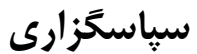
با سياس فراوان از همكارى معاونت محترم يزوهش و فناورى دانشعاه آزاد اسلامى واحد تنكابن كه در تصويب و تامين هزينه هاى اين طرح تحقيقاتى از محل بودجه يثوهشى كمال همكارى را داشته و هم جنين كارشناسان آزمايشگاه گروه ميكروبيولوزى كه امكان انجام اين تحقيق را ميسر نمودند تشكر و و قدردانى مى نمايم.

\section{References}

1.Suleyman G, Alangaden GJ.Nosocomial Fungal Infections: Epidemiology, InfectionControl, and Prevention.Infec Dis Clin North Am 2016;30:1023-52.

2. Curtis, LT. Prevention of hospitalacquiredinfections review of non pharmacological interventions. J Hosp Infect 2008;69:204-19.

3.Shi JY, Xu YC, Shi Y, Lu HX, Liu Y, Zhao WS, et al. In vitro susceptibility testing of Aspergillus spp. against voriconazole itraconazole posaconazole amphotericin B and caspofungin. Chin Med J 2010; 123:2706-9.

4. Kordbacheh P, Zaini F, Kamali P, Ansari $\mathrm{K}$, Safara M. [Study on the sources of nosocomial fungal infections at ICU and transplant wards at a teaching hospital in
از آمفوتريسين B مى باشد و به عنوان اولين رده دارويى براى اين بيمارى به تصويب رسيده است. هم

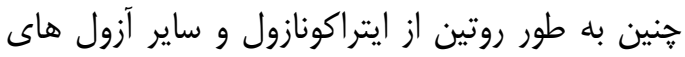
خوراكى يا تزريقى استفاده مى شود. داروى اكينوكاندين در موارد شكست درمانى ساير آنتى فانگال ها و يا عدم تحمل ساير دارو نيز مورد استفاده قرار مى گيردا. در دران

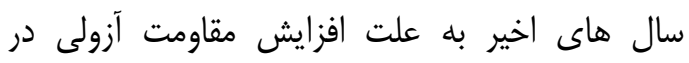

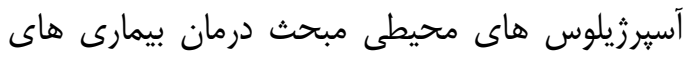
حاصل از آن ها سبب مشكلات بسيار مهمى كرديديد است زيرا گَترش مقاومت دارويى مى تواند در كنترل بيمارى هاى ناشى از اين قارج ها اختلال ايجاد كناد كند

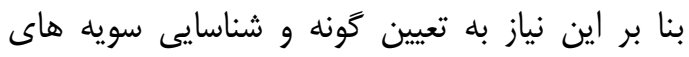

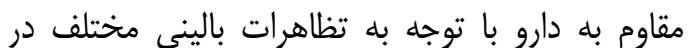
بيماران دجار آسيريلوزيس مهاجم هستيم(ها؟). با توجه به نتايج مطالعه صورت كرفته در اين

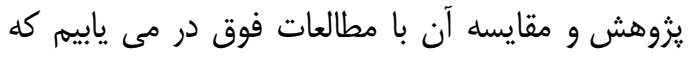

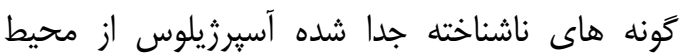
هاى متفاوت به ويزه بيمارستانى ممكن است نسبت به داروهاى ضد قارجى حساسيت هاى مختلفى نشان دهند. تفاوت در نتايح تست حساسيت دارويى مى تواند

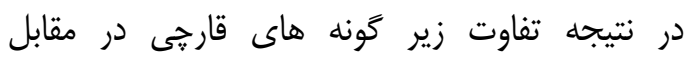
داروهاى مورد بررسى، مقاومت سويه ها نسبت بك بكانه داروهاى ضد قارجى، ا ختلاف در كيفيت داروى توليد

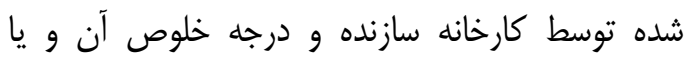

Tehran]. Iranian J Pub Health 2005;34: 1-8. (Persian)

5. Vandewoude $\mathrm{KH}$, Vogelaers $\mathrm{D}$, Blot SI.Aspergillosis in the ICU-the new 21 st century problem? Med Mycol 2006; 44: 716.

6. Zilberberg MD, Shorr AF.Fungal infection in the ICU. Infect Dis Clin North Am 2009; 23:625-42.

7.Nabili M, Moazeni M, Taghizadeh Armaki M, Asgari MR, Nosrati A, Shokohi T. [Diagnostic Tools in Fungal Infections since Classical to Molecular Era] . J Mazandaran Uni Med Sci 2013;23:109-29. (Persian)

8.Denning DW,Venkateswarlu K, Oakley KL, Anderson MJ, Manning NJ. Itraconazole resistance in Aspergillus 
fumigatus. Antimicrob Agents Chemo1997; 41:1364-8.

9. Howard SJ, Arendrup MC.Acquired antifungal drug resistancein Aspergillus fumigatus epidemiology and detection. Med Mycol 2011; 49: 90-5.

10. Arujo R, Amorim A, Gusma oL. Genetic diversity of Aspergillus fumigatus in indoor hospital environments. Med Mycol 2010; 48: 832-38.

11. Chazalet V, Debeaupuis JP, Sarfati J, Lortholary J, Ribaud P, Shah P, Molecular typing of environmental and patient isolates of Aspergillus fumigatus from various hospital settings. J Clin Microbiol1998 Jun;36:1494-500.

12. Hinrikson HP, Hurst SF, Agurre SF. Morrison CJ.Molecular methods for the identification of Aspergillus species. Med Mycol 2005; 43:129-37.

13. Hinrikson H P, Hurst S F, Lott TJ, Warnock DW, C J Morrison. Assessment of Ribosomal Large-Subunit D1-D2, Internal Transcribed Spacer 1, and Internal Transcribed Spacer 2 Regions as Targets forMolecular Identification of Medically Important Aspergillus Species. J Clin Microbiol 2005;43:2092-103.

14. Wayne PA . Reference method for broth dilution antifungal susceptibility testing of Filamentous fungi $.2^{\text {th }}$ ed. CLSI Clin Lab Standards Institute Publication. 2008. P.

15. Lassflorl C. Invitro susceptibility testing in Aspergillus species an update. Future Microbio 2010;5:789-99.

16.Garciacruz CP, Najeraaguilar MJ, Arroyohelguera OE. Fungal and bacterial contamination on indoor surfaces of a hospital in Mexico. Jundishapur J Microbiol 2012;5:460-4.

17. Diba K, Khadijeh Makhdoomi K, Mirhendi H.Molecular characterization of Aspergillus infections in an Iranian educational hospital using RAPD-PCR method. Iran J Basic Med Sci 2014; 17:646-50.

18. Denning DW, Ribaud P, Milpied N, Caillot D, Herbrecht R, Thiel E, et al.
Efficacy and safety of voriconazole in thetreatment of acute invasive aspergillosis. Clin Infect Dis 2002; 34:563-71.

19Hashemi SJ , Zaini F , Daie R, Zibafar E , Zakeri MA .A.[Invitro susceptibility of Aspergillus species isolated from cutaneous andvisceral lesions to antifungal agents]. Tehran Uni Med J 2011; 69:83-91. (Persian)

20.Araujo R, Coutinho I, Espinel-Ingroff A.Rapid method for testing the susceptibility of Aspergillus fumigatus to amphotericin $\mathrm{B}$, itraconazole, voriconazole and posaconazoleby assessment of oxygen consumption. J Antimicrob Chemother 2008; 62:1277-80.

21. Hojatinia H, Sabokbar A. Sensitivity determination of Aspergilus flavus to Itraconazol Voriconazol and Caspofungin. NCMBJ 2016; :51-8

22.Hoseinnejad A, Hedayati MT, Moazeni M, Taghizadeharmaki M, Abastabar M, Jabariamiri MR, et al. [Antifungal susceptibility testing of 90 clinical and environmental isolates of Aspergillus flavus to Voriconazole and Itraconazole].J Mazandaran Uni Med Sci 2016; 25:91-99. (Persian)

23.Chen Y, Lu Z, Zhao J, Zou Z, Gong Y, Bao Z, Qiu G tal. Epidemiology and molecular characterizations of Azole resistance in clinical and environmental Aspergillus fumigatus isolates from China. Antimicrob Agents Chemo 2016; 60:5878-84.

24. Tangwattanachuleeporn $M$, Sasse $C$, Buchheidt D, Weig M, Grob U, Bader O. Molecular tools for the detection and deduction of azole antifungal drug resistance phenotypes in Aspergillus species. Clin Microbiol Rev 2017;30 :106591.

25. Enoch DA, Aliyu SH, Micallef C.The changing epidemiology of invasive fungal infections. Meth Mol Biol 2017; 1508:1765. 


\title{
Evatuation of Drug susceptibility of Aspergillus species Isolated from ICU of Hospitals in Invitro
}

\author{
Nasrolahiomran $A^{l *}$
}

(Received: May 6, 2017

\begin{abstract}
Introduction: Invasive aspergillosis is the most threatening disease inimmunocompromised patients which has the highest morbidity and mortality rate among invasive fungal infections in the hospitals. The aim of present study was to assess antifungal susceptibilitytesting versus Aspergillus spp isolated from the hospitals environment.
\end{abstract}

Materials \& Methods: After collecting 160 plates containing Sabouraud dextrose agar from the air and the environment of hospital's ICUs (intensive care units), the phenotypic and molecular identification of the colonies was performed for the identification of Aspergillusspp. After DNA extraction, the molecular identification was carried out using universal fungal primers (ITS gene) and DNA sequencing. Antifungal susceptibility testing was performed using the CLSI broth microdilution (M38-A2) method for Aspergillus isolates.
Accepted: November 15, 2017)

Findings: Out of 160 hospital environmental samples, 11Aspergillus species were obtained. The eleven Aspergillus spp. were identified by sequencing as: $5 \mathrm{~A}$. flavus, $3 \mathrm{~A}$. sydowii, 1 A. fumigates and 2A. Oryzae. Our antifungal susceptibility testing results indicated that $\mathrm{A}$. sydowii and $\mathrm{A}$. fumigatus were sensitive to Amphotericin and Voriconazole and also were resistant to Itraconazole. A. sydowii was resistant to Caspofungin while A.fumigatus was sensitive to this drug. A. flavus was susceptible to all the drugs.

Discussion \& Conclusions: There were a number of reasons including delayed diagnosis, lack of appropriate curing, and the existence of various diseases and neutropenia which could lead to the high mortality rate of patients with Aspergillosis, especially in patients of hospital's ICUs.

Keywords: Drug susceptibility, Aspergillus SP. ICU

1. Dept of Mycology, Faculty of Medicine, Islamic Azad University, Tonkabon Branch,Tonkabon, Iran

* Correspondin author Email: Ayat51@yahoo.com 